\title{
Evaluation of Curriculum Implementation 2013 Batubara District
}

\author{
Mauluddin M Noor \\ Graduate Student of Sport Education \\ State Universitas Negeri Medan \\ Medan, Sumatera Utara \\ E-mail: \\ mauluddin21noor@gmail.com
}

\author{
Albadi Sinulingga \\ Graduate Lecturer of Sport \\ Education \\ State Universitas Negeri Medan \\ Medan, Sumatera Utara
}

\author{
Sanusi Hasibuan \\ Graduate Lecturer of Sport \\ Education \\ State Universitas Negeri Medan \\ Medan, Sumatera Utara
}

\begin{abstract}
The implementation research of Curriculum 2013 in Batubara Regency found many obstacles at the beginning of its application. This study aims to evaluate the implementation of Curriculum 2013 in Coal District. The components of the evaluated curriculum implementation include: the condition of the student, the condition of the teacher, the teacher's understanding of the curriculum, the condition of the infrastructure, the instructional planning, the implementation of the scientific. The implementation of authentic assessment, and the results of authentic assessment related aspects of attitude, knowledge, and skills. The evaluation model used is the evaluation model of Stake Countenance Models. Evaluation is done by collecting information in the form of data component of the curriculum implementation to then be compared with the standards of the ministry. The population consists of Senior vocational high school. Subject of research is principal and teacher determined by purposive sampling technique. The instruments used are questionnaires, observation sheets, and documentation sheets. Trial of questionnaire instrument was conducted at Senior vocational high school in Batubara district. Data analysis using descriptive technique. Research result, student condition of $93.4 \%$, teacher's condition of $75 \%$, infrastructure condition of $69.3 \%$. The proposed recommendations are: Student condition: active and creative teachers. Teacher condition: Increased academic qualifications in cooperation with related parties. Teachers must be orderly administration and conduct learning in accordance with the standards of learning implementation.
\end{abstract} 2013

Keywords: evaluation, curriculum implementation, Curriculum

\section{INTRODUCTION}

In the early stages of the study, researchers conducted interviews with sports teachers in the existing Vocational Schools in Batubara District as well as school principals as implementers of the 2013 curriculum. The results of the interviews were also summarized in the 2013 Curriculum Assistance Evaluation Meeting of Principals in Coal District and obtained several problems perceived as still a constraint in the implementation of the 2013 curriculum including in the preparation, implementation and evaluation / assessment stages.

The preparation stage, not all teachers are skilled in operating IT so that it impedes the smooth running of tasks such as RPP production, value processing, using multimedia learning media, and others. Students' books in class XI arrived at school took quite a long time, and the books used used books in the form of Pdf. Learning materials in student books and teacher books are very minimal so they must use relevant accompanying books.

Teachers also experience constraints in implementation, including class $\mathrm{X}$ students who are difficult to be active in learning due to the old means. While based on the opinion of the implementing teacher 2013 Curriculum (Meeting Evaluation of Assistance 2013 Curriculum Principals in Batubara Regency, 2013), the material in the Student Book requires mastery of the material and independent learning. Another obstacle is the implementation of learning cannot be completed in one meeting or one day because of the many activities that must be done by teachers and students. In learning the teacher performs authentic assessments for each aspect, and students complete solid learning activities.

The teacher also has difficulty in accommodating the scientific approach with 5 steps (observing, asking, trying, reasoning, communicating) in learning activities. This difficulty is added when the child is less active, even though the demands with this scientific approach, students must be active. For class X students, at first they were still confused with the concept of saintific learning because they were familiar with the subject matter delivered by the teacher. In certain learning materials, it is often found that there is no connection or even if there is a connection, it seems forced. This is based on the opinions of teachers summarized in the 2013 Curriculum Assistance Evaluation Meeting for Principals in Batubara District.

Constraints in the evaluation / assessment stage faced by the teacher include: an authentic grading system cannot be done maximally by the teacher considering the large number of students and the many elements of assessment. This includes setting up a list of values, a book on learning outcomes (report cards). Teachers do not understand the assessment guidelines so that it is difficult to make UTS / UAS questions in revealing aspects of knowledge whether referring to themes or subjects. Parents / guardians of students also experience difficulties in guiding learning at home because they are still confused with the concept of scientific learning. The 2013 curriculum requires parents to be proactive 
in guiding and preparing tools / materials for school activities. This is a problem for parents who are too busy.

Constraints that exist in the initial implementation phase of the 2013 Curriculum, should immediately be explored in depth to find the most feasible solution. From the evaluation results of the 2013 Curriculum implementation team in the first year that found there were still obstacles / obstacles, researchers wanted to know whether after the 2013 curriculum implementation in vocational schools and already producing graduates there were still obstacles / obstacles in implementation and to what extent the 2013 curriculum implementation was viewed from various aspects such as the condition of the students, the condition of the teacher, the condition of the infrastructure, the preparation of learning plans, the implementation of learning, and the assessment of learning. Therefore an evaluation will be conducted.

There are 7 evaluation models in education models, In the problems faced in Batubara district related to the 2013 curriculum evaluation it can be seen from the description above can be used to evaluate Stake's Model. Evaluation of Stake's Model has the same objectives as the problems in the Coal district to solve or to solve problems in the district of Coal. The research issue that will be carried out is the 2013 SMK Curriculum Evaluation in Coal Regency.

\section{METHODOLOGY}

Subjects of the study on curriculum evaluation were conducted on teachers, students, principals and the process of implementing 2013 vocational curriculum in Batubara district in 2018/2019 academic year. A total of 13 Vocational Schools in the Coal Regency implemented the 2013 curriculum with 13 school principals, 20 physical education teachers. All members of the principal and teacher population are used as respondents. The determination of the teacher's sample uses the Total sampling technique on the basis that all physical education teachers of Vocational Schools in the Coal Regency are familiar with the 2013 curriculum, Data collection techniques, questionnaires, observation and documentation.

Analysis techniques used are data analysis techniques according to the Stake model, namely by comparing the results data obtained with predetermined criteria. Researchers describe conditions, activities with quantitative data descriptions. Criteria for questionaire processing using criteria from Djemari Mardapi (2008: 123).

Information obtained from observations using observation sheets will be analyzed descriptively using criteria from the Ministry of Education and Culture (2013: 314). Criteria for observing the condition of infrastructure, implementation of learning, teaching planning, assessment results as follows:

TABLE 1. CRITERIA FOR OBSERVING

\begin{tabular}{|c|c|c|}
\hline NO & Percentage $(\boldsymbol{\%})$ & Criteria \\
\hline 1. & $80,01 \%-100 \%$ & Very Good \\
\hline 2. & $60,01 \%-80 \%$ & Good \\
\hline 3. & $40,01 \%-60 \%$ & Less \\
\hline 4. & $0 \%-40 \%$ & Very lacking \\
\hline
\end{tabular}

\section{RESULTS AND DISCUSSION}

This research was conducted in a Batubara district with a sample of 13 vocational secondary schools, 20 physical education teachers and 13 school principals. This research will be carried out by raising the issue of curriculum implementation evaluation that has been implemented in Batubara Regency within a period of 4 years, the evaluation method used is the evaluation model of stake's countenece. This evaluation model is a model that presents data in three parts including: 1) antecedene, 2) transactions, and 3) outcomes. This evaluation model makes it easy for researchers to conduct a 2013 curriculum evaluation in coal districts and also through this stake's countenece evaluation model, can provide advice but not make decisions.

From the research that has been implemented using the evaluation model of Stake Countenance, can be seen from eight instruments that spread, three of the instruments of the student condition, the condition of the teacher and the condition of infrastructure obtained results that show The success rate of 2013 curriculum implementation in coal district is seen from the student condition of $93.4 \%$, teacher's condition $75 \%$ and facility condition of infrastructure $69.3 \%$.

TABLE 2. STUDENT CONDITION

\begin{tabular}{|c|c|c|c|c|}
\hline No & Criteria & $\begin{array}{c}\text { Total } \\
\text { Responden }\end{array}$ & $\begin{array}{c}\text { Score } \\
\text { Maksimal }\end{array}$ & Percentage \\
\hline $\mathbf{1 .}$ & Very Good & 123 & 301 & $40,9 \%$ \\
\hline $\mathbf{2 .}$ & Good & 158 & 301 & $52,5 \%$ \\
\hline $\mathbf{3 .}$ & Less & 20 & 301 & $6,6 \%$ \\
\hline $\mathbf{4 .}$ & Very lacking & 0 & 301 & $0 \%$ \\
\hline & Total & 301 & & $100,0 \%$ \\
\hline
\end{tabular}

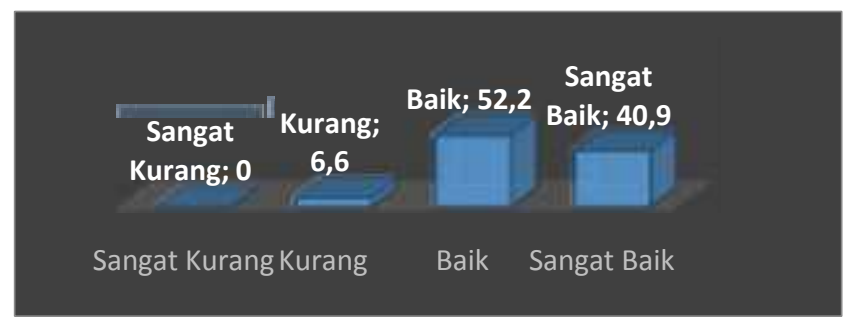

Fig. 1. Student Condition

TABLE 3. TEACHER CONDITION

\begin{tabular}{|c|c|c|c|c|}
\hline No & Criteria & $\begin{array}{c}\text { Total } \\
\text { Score }\end{array}$ & $\begin{array}{c}\text { Score } \\
\text { Maksimal }\end{array}$ & Percentage \\
\hline 1. & Very Good & 7 & 20 & $35 \%$ \\
\hline 2. & Good & 8 & 20 & $40 \%$ \\
\hline 3. & Less & 3 & 20 & $15 \%$ \\
\hline 4. & Very lacking & 2 & 20 & $10 \%$ \\
\hline & Total & 20 & & $100,0 \%$ \\
\hline
\end{tabular}




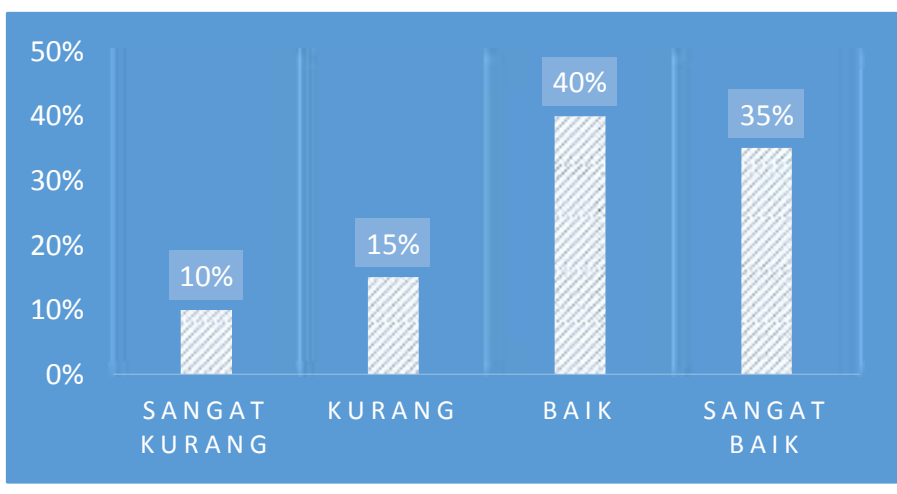

Fig. 2. Teacher Condition

TABLE 4. FACILITY CONDITION OF INFRASTRUCTURE

\begin{tabular}{|c|c|c|c|c|}
\hline No & Criteria & $\begin{array}{c}\text { Total } \\
\text { Responden }\end{array}$ & $\begin{array}{c}\text { Total } \\
\text { Responden }\end{array}$ & Percentage \\
\hline 1. & Very Good & 5 & 13 & $38,5 \%$ \\
\hline 2. & Good & 4 & 13 & $30,8 \%$ \\
\hline 3. & Less & 3 & 13 & $23,1 \%$ \\
\hline 4. & Very lacking & 1 & 13 & $7,6 \%$ \\
\hline & Total & 13 & & $100 \%$ \\
\hline
\end{tabular}

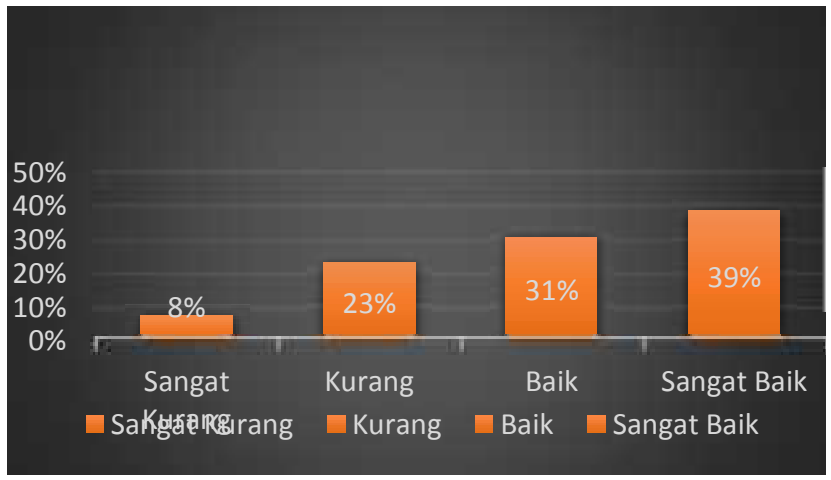

Fig. 3. Facility condition of infrastructure

\section{CONCLUSIONS AND RECOMMENDATIONS}

Evaluation of Implementation curriculum 2013 research that will be held in the Batubara district is expected to produce an idea and input to steakholders to be taken into consideration in applying the curriculum to schools as well as knowing the weaknesses and strengths of the implications of the 2013 curriculum starting from the initial implementation, core and final results of the curriculum applied.

The research results can be concluded as follows:

1. Antecedent Stage (introduction)

a. condition students are seen from the aspects of lesson readiness and active during learning not yet fully compliant with a percentage of $93.4 \%$ and a very good category

b. The teacher's condition is seen from the aspect of academic qualifications, pedagogic competence, personality competence, social competence, and professional competence is not fully compliant with the percentage of $75 \%$, and well-categorized

c. Condition of infrastructures seen from classrooms and its completeness, library space, and props/media in the laboratory are well-categorized with a percentage of $69.3 \%$.

Input :

1. Improved student condition can be done by means of active and creative teachers in motivating students of the importance of learning. Teachers can apply rewards and punishment in a balanced and fair manner to improve student motivation. It can be done with simple things such as giving greeting cards to students who have made a learning awareness increase, announcing the good thing that students already have done in front of friends in order to add a will in Learn and so on.

2. Consideration to improve the teacher's condition of increasing academic qualifications in collaboration with related parties, increasing the competency of teachers with training and self-development programs, improving the leadership role of the Principal, cooperation with the Education Office and LPMP.

3. Increased use of infrastructure \& in schools for learning activities. Schools should have a program of use \& infrastructures such as a) to make activities outside the hours of study (compulsory program to follow the exposition of the sport in the school, the student Competition program that uses the existing sports facilities in the school, A picket program for upscale students to help care for equipment and sports equipment that exist in the school); b) Make the use of equipment and procurement of sports equipment that does not exist; c) Maintenance, inventory, and procurement of sports facilities \& school infrastructure regularly.

\section{REFERENCES}

[1] Asiyai, R. (2014). Students'perception of the condition of their classroom physical learning environment and its impact on their learning and motivation. College Student Journal. Winter2014, Vol. 48 Issue 4, p716726. $11 \mathrm{p}$.

[2] Cheung, A.C.K. \& Wong, P.M. (2011). Effects of school heads' and teachers' agreement with the curriculum reform on curriculum development progress and student learning in Hong Kong. The International Journal of Educational Management, 25.5 : 453-473.

[3] Fernandes, H.J.X. (1984). Evaluation educational of program. Jakarta: National Education planning evaluation and curriculum development.

[4] Hosnan. (2014). Pendekatan saintifik dan kontekstual dalam pembelajaran abad 21. Jakarta: Ghalia Indonesia.

[5] Labane, N. (2009). Planning and managing curriculum implementation in rural schools: an investigation. Nelson Mandela Metropolitan University.

[6] Moschetta, H.M. (2010). Development, evaluation, and implementation of the secondary english curriculum evaluation. (Disertasi doktor, Robert Morris University, 2010). University Microfilms International number: 3442978.

[7] Muri, Y. 2015. Asesmen dan Evaluasi Pendidikan. Pilar Penyedia Informasi dan Kegiatan Pengendalian Mutu Pendidikan. Jakarta : Prenadamedia Group. 